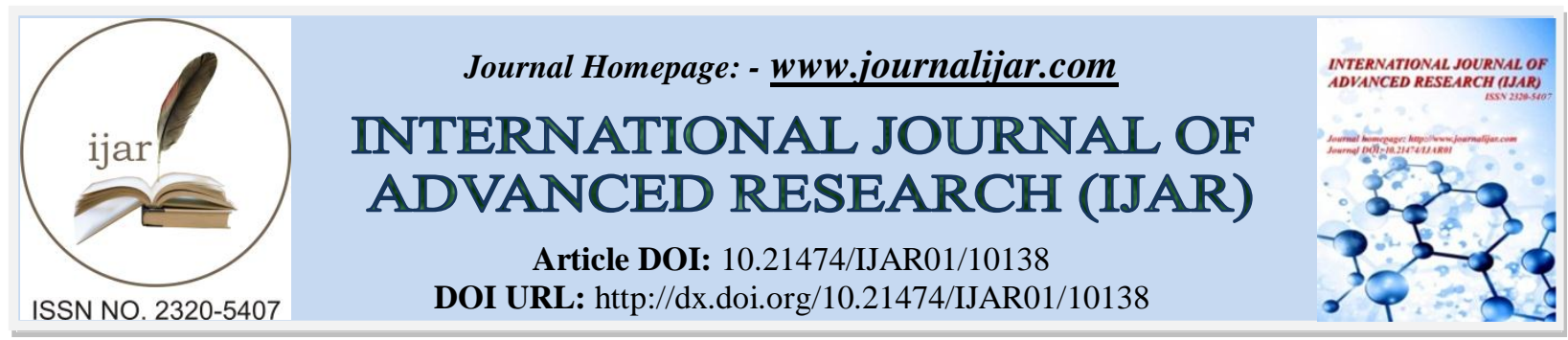

RESEARCH ARTICLE

\title{
COMPARISON OF LOAD DEFLECTION PROPERTIES AND FRICTIONAL RESISTANCE OF CONVENTIONAL NITI ARCHWIRES AND COATED NITI ARCHWIRES GENERATED IN VARIOUS CERAMIC BRACKET SLOTS- AN IN-VITRO STUDY.
}

Dr. Rahul Aghera ${ }^{1}$, Dr. Hina Desai ${ }^{2}$, Dr. Kalpesh Patel ${ }^{3}$, Dr. Udita A. Thakkar ${ }^{4}$ and Dr. Nikunj Patel ${ }^{5}$

1. Private Practioner, Vadodara, Guajrat. India.

2. HOD, Department of Orthodontics, Manubhai Patel Dental college and Hospital, Vadodara, Guajrat. India.

3. Professor, Department of Orthodontics, Manubhai Patel Dental college and Hospital, Vadodara, Guajrat. India.

4. Senior Lecturer, Department of Orthodontics, Manubhai Patel Dental college and Hospital, Vadodara, Guajrat. India.

5. Reader, Department of Orthodontics, Manubhai Patel Dental college and Hospital, Vadodara, Guajrat. India.

\section{Manuscript Info}

\section{Manuscript History}

Received: 01 October 2019

Final Accepted: 03 November 2019

Published: December 2019

Key words:-

Coated NiTi archwire, ceramic brackets, frictional resistance, load deflection properties.

\begin{abstract}
Introduction:-Two main groups of materials used in fixed orthodontics are brackets and archwires. The present study was done to compare the frictional resistance and load-deflection properties of conventional NiTi archwire, Teflon coated NiTi archwire and Epoxy resin coated NiTi archwire when placed within the slot of ceramic brackets, metal-insert ceramic brackets and self- ligating ceramic brackets.

Method: The frictional resistance (static friction and kinetic friction) and load-deflection properties (loading and unloading forces) of conventional NiTi, Teflon coated NiTi and Epoxy resin coated NiTi archwires (0.019"x0.025") were evaluated when placed within the slot of ceramic bracket, ceramic bracket with metal slot and ceramic self ligating bracket (0.022" 0.028 " MBT prescription). 54 samples were tested (6 per group) using Universal Testing Machine.

Results: Least static and kinetic friction was found when Epoxy resin coated NiTi wire was used with ceramic self ligating bracket. Highest static friction was found when Teflon coated NiTi wire was used with ceramic self ligating bracket. Least loading and unloading forces were found when Epoxy resin coated NiTi wire was used with ceramic self ligating bracket. Highest loading and unloading forces were found when Teflon coated NiTi was wire used with ceramic bracket. Conclusion: Epoxy resin coated archwire showed had more potential to reduce the friction and produced less loading and unloading forces as compared to Teflon coated archwire and conventional NiTi arch wire. Ceramic self ligating brackets and ceramic brackets with metal slot produced low frictional forces as compared to conventional ceramic brackets.
\end{abstract}

Copy Right, IJAR, 2019,. All rights reserved.
Corresponding Author:-Dr. Rahul Aghera.

Address:-Private Practioner, Vadodara, Guajrat. India. 


\section{Introduction:-}

Several authors have commented on the increase in the number of adults coming for orthodontic treatment. This phenomenon has been attributed to various factors including the improved appearance of fixed appliances, increased awareness of the possibilities of orthodontic treatment, and the social acceptability of fixed appliances ${ }^{1}$. Orthodontic patients, including a growing population of adults, not only want an improved smile, but they are also increasingly demanding lesser visibility of appliance during treatment ${ }^{2}$.

Two main groups of materials used in fixed orthodontics are brackets and archwires ${ }^{3}$. Ceramic brackets were introduced in the 1980's, offering many advantages over the traditional orthodontic appliances. Ceramic brackets provide higher strength, more resistance to wear and deformation, better colour stability and most important to the patient, superior aesthetics ${ }^{2}$. All currently available ceramic brackets are composed of aluminium oxide in one of two forms: polycrystalline or monocrystalline depending on their distinct method of fabrication. Ceramic brackets are available in various types such as conventional, self ligating and metal-insert ${ }^{2}$.

In terms of archwires, three types of esthetic archwires are introduced. Optiflex, which did not, have desirable mechanical properties. Fiber-reinforced composite archwire is still at laboratory level, and coated metallic archwire, which is currently the only clinically used esthetic wire. The materials used in coatings are tooth-colored teflon (polytetrafluoroethylene) or epoxyresin and rhodium coated ${ }^{3}$. Disadvantages in durability and surface properties such as tearing and colour changing of these coatings in clinical conditions have been reported ${ }^{3}$.

The mechanical properties of orthodontic archwires can be assessed by using a 3-POINT bending test, which evaluates the load-deflection properties, considered one of the most important parameters to determine the biologic nature of tooth movement, and provides information on the behaviour of wires when subjected to deflection in the horizontal and vertical directions 4 .

FRICTION is defined as the resistance to motion when a solid object moves tangentially against another solid object. Friction (resistance to sliding) between the bracket and wire (archwire) during orthodontic tooth movement is an important factor in clinical orthodontics because a decrease in friction might shorten the treatment period and also improve anchorage control ${ }^{5}$.

Since the coefficient of friction of aesthetic ceramic brackets are greater than that of the metal brackets, it is necessary to consider the changes in friction between the ceramic brackets and orthodontic wires ${ }^{6}$. Coating of archwires may influence over their mechanical properties too. Husmann et al showed that coatings decreased frictional force. Elayyan et al., found that epoxy resin coated archwires produced lower frictional force compared to uncoated wires of the same sizes ${ }^{3}$.

Hence the present study was done to compare the friction resistance and load-deflection properties of conventional and coated NiTi archwires when placed within the slot of ceramic brackets, metal-insert ceramic brackets and selfligating ceramic brackets when esthetic appliance is the demand or need for an adult patient especially.

\section{Materials and Method:-}

The frictional resistance and load-deflection properties of conventional and coated NiTi archwires were evaluated when placed within the slot of various ceramic brackets. This study was carried out at Department of Orthodontics and Dentofacial Orthopedics, Manubhai Patel Dental College and ORI, Vadodara.

Materials:-

Table 1:- Arch wires

\begin{tabular}{|c|c|c|}
\hline Name & $\begin{array}{l}\text { Dimensions } \\
\text { (inches) }\end{array}$ & Manufacturer \\
\hline Teflon coated Ni-Ti archwire & $0.019 " \times 0.025 "$ & G\&H wire \\
\hline Epoxy coated Ni-Ti archwire & $0.019 " \times 0.025 "$ & $\begin{array}{l}\text { RABBIT FORCE (LIBERAL TRADERS) } \\
\text { Imported from G\&H wire }\end{array}$ \\
\hline Conventional Ni-Ti archwire & $0.019 " \times 0.025 "$ & G\&H wire \\
\hline
\end{tabular}




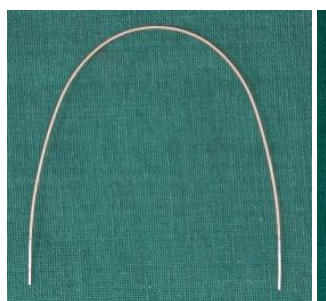

Fig. 2:-Teflon coated NiTi

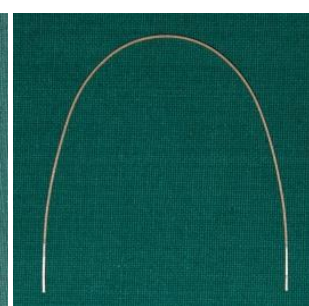

Fig. 3:-Epoxy resin coated NiTi

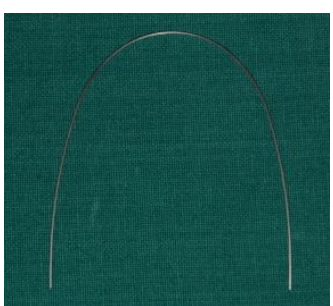

Fig. 4:-Conventional NiTi

\section{Brackets:}

Bondable ceramic brackets (polycrystalline) of 0.022 " x 0.028 " slot MBT prescription (American Orthodontics).

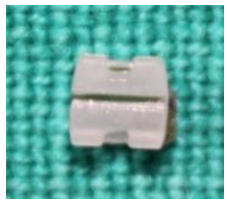

Fig. 5:- Ceramic bracket $(0.022 " x$ x $0.028 "$ slot $)$

Bondable ceramic metal slot brackets (polycrystalline) of 0.022 "x 0.028 " slot MBT prescription (American Orthodontics).

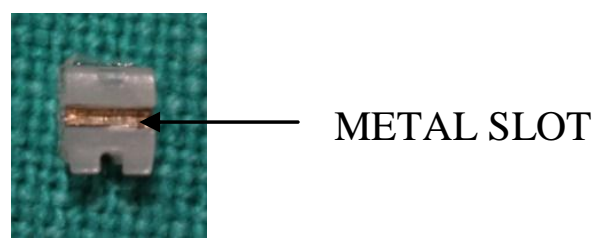

Fig 6:- Ceramic bracket with metal slot $(0.022$ " x 0.028 " slot $)$

Bondable ceramic self-ligating brackets of 0.022 " x 0.028 " slot MBT prescription (American Orthodontics).

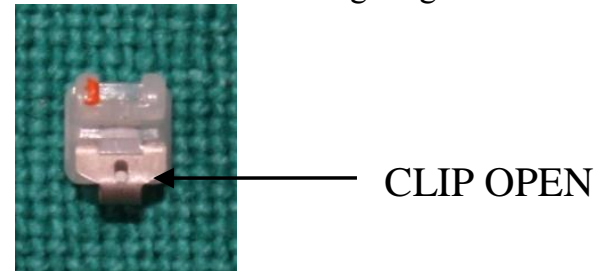

Fig. 6(a):- Ceramic self ligating bracket open

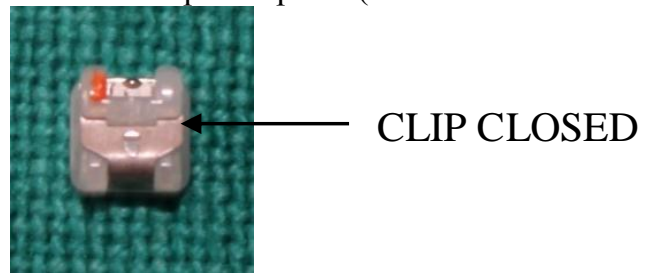

Fig. 6(b):- Ceramic self ligating bracket closed

\section{Ligatures:-}

1. Clear elastomeric modules $(\mathrm{G} \& \mathrm{H})$

2. Universal Testing Machine

3. Composition of test groups

Table 7:- Distribution of brackets and archwires into groups and subgroups

\begin{tabular}{|l|l|l|}
\hline \multicolumn{2}{|l|}{ GROUPS } & \multicolumn{2}{|l|}{ SPECIMENS } \\
\hline \multirow{4}{*}{$\begin{array}{l}\text { Group I } \\
\text { (Teflon } \\
\text { NiTi) }\end{array}$} & Group I a & $\begin{array}{l}\text { Ceramic brackets with Teflon coated NiTi } \\
\text { archwires }\end{array}$ \\
\cline { 2 - 3 } & Group I b & $\begin{array}{l}\text { Ceramic metal slot brackets with Teflon } \\
\text { coated NiTi archwires }\end{array}$ \\
\cline { 2 - 3 } Group II & Group I c & $\begin{array}{l}\text { Ceramic self-ligating brackets with Teflon } \\
\text { coated NiTi archwires }\end{array}$ \\
\cline { 2 - 3 } & Group II a & $\begin{array}{l}\text { Ceramic brackets with Epoxy coated NiTi } \\
\text { archwires }\end{array}$ \\
\cline { 2 - 3 } & Group II b & Ceramic metal slot brackets with Epoxy \\
\hline
\end{tabular}




\begin{tabular}{|l|l|l|}
\hline $\begin{array}{l}\text { (Epoxy resin } \\
\text { coated NiTi) }\end{array}$ & Group II c & loated NiTi archwires \\
\cline { 2 - 4 } & Group III a & $\begin{array}{l}\text { Ceramic self-ligating brackets with Epoxy } \\
\text { coated NiTi archwires }\end{array}$ \\
\hline \multirow{2}{*}{$\begin{array}{l}\text { Group III } \\
\text { (Conventional } \\
\text { NiTi) }\end{array}$} & Group III b & $\begin{array}{l}\text { Ceramic brackets with conventional NiTi } \\
\text { archwires }\end{array}$ \\
\cline { 2 - 4 } & Group III c & $\begin{array}{l}\text { Ceramic metal slot brackets with conventional } \\
\text { NiTi archwires }\end{array}$ \\
\hline
\end{tabular}

\section{Sample size:}

Minimum observations required for proposed study were 54 (6 per group) to detect effect size of 3.19 at $5 \%$ risk and $90 \%$ power.

\section{Friction test:}

The static and kinetic frictional force generated with each wire/ bracket combination was measured under dry conditions and at room temperature using a universal testing machine (ACME Engineers, India, Model No. UNITEST-10). The custom made stainless steel jig was fabricated to which brackets were bonded. Each bracket was bonded with adhesive to a stainless steel plate. The stainless steel plate with the bracket was attached to the frictiontesting device, and a 5-cm segment of wire was then ligated to the bracket with an elastomeric ligature (Clear elastomeric modules, $G \& H$ ), except the self-ligating brackets were tested in a closed position. The upper end of the wire was fixed in a grip that was attached to the load cell. Each wire was drawn through the bracket at a cross-head speed of $3 \mathrm{~mm} / \mathrm{min}$ for a distance of $5 \mathrm{~mm}$. The static and kinetic frictional force were determined from loaddisplacement curves ${ }^{6}$.

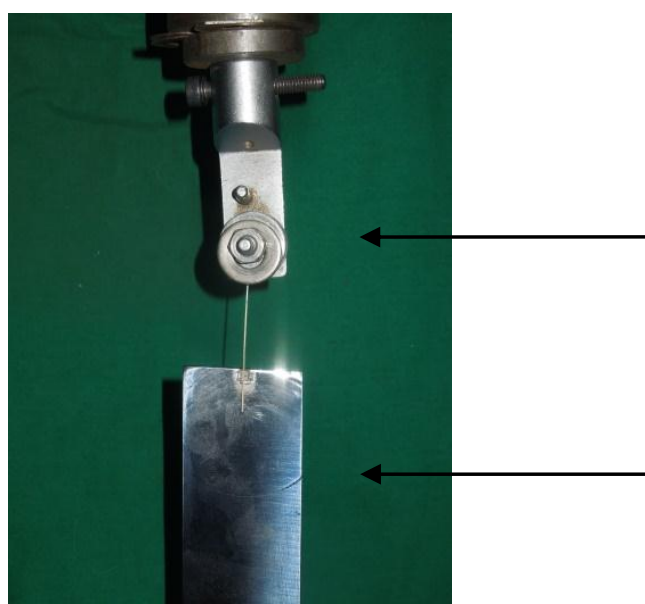

\section{LOAD CELL}

STAINLESS STEEL JIG

Fig.8:-Custom made stainless steel jig attached to Universal testing machine.

\section{Three point bending test:}

The load - deflection characteristics of specimens from each group were evaluated using three- point bending test. A specially designed jig with two supports $14 \mathrm{~mm}$ apart was fabricated. The test wire specimens were secured on brackets fixed on the poles using elastomeric ligatures (Clear elastomeric modules, G\&H), except the self-ligating brackets were tested in a closed position. Testing was done using a Universal testing machine (Star Testing Machine, model no. STS 248). The striker was attached to the upper movable head of the Instron machine. The tip of the striker was on the centre of the test-wire span. The crosshead speed for loading and unloading was $3 \mathrm{~mm}$ per minute. The mid portion of the wire was deflected. The loading values for each sample were recorded at 1, 2 and 3 $\mathrm{mm}$ deflections and the unloading values at $0.5,1.5$ and $2.5 \mathrm{~mm}^{7}$. 


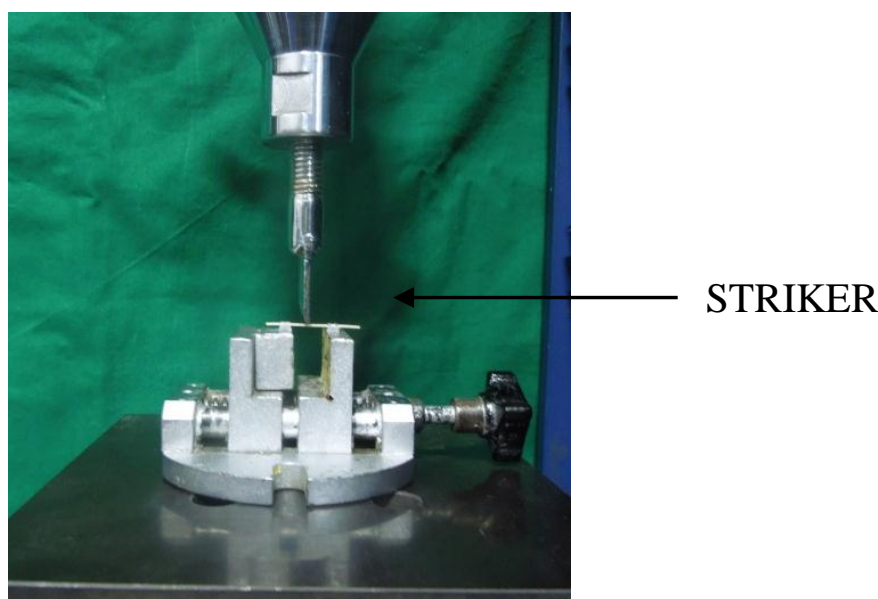

Fig 9:- Tip of the striker of Instron machine on the centre of the test-wire span.

\section{Statistical Analysis}

Descriptive statistics, including means and standard deviations values were calculated for the static friction, kinetic friction, loading forces at $3 \mathrm{~mm}$ and unloading forces between $2.5 \mathrm{~mm}-1.5 \mathrm{~mm}$ produced by each bracket and wire combinations. This test was followed by Tukey's honestly significant difference (HSD) test for multiple comparisons of means, at $\mathrm{p}<0.05$, to determine differences among the different groups.

\section{Results:-}

The static and kinetic frictional force generated with each wire/ bracket combination was measured using a universal testing machine. Each wire was drawn through the bracket at a cross-head speed of $3 \mathrm{~mm} / \mathrm{min}$ for a distance of 5 $\mathrm{mm}$. The static and kinetic frictional forces were determined from load-displacement curves.

Table 10:- Comparison of static friction (N)

\begin{tabular}{|l|l|l|l|l|l|l|}
\hline \multicolumn{2}{|l|}{ GROUPS } & SAMPLE & $\begin{array}{l}\text { MEAN } \\
(\mathbf{N})\end{array}$ & $\begin{array}{l}\text { STD. } \\
\text { DEVIATION } \\
\text { (N) }\end{array}$ & $\begin{array}{l}\text { MINIMUM } \\
(\mathbf{N})\end{array}$ & $\begin{array}{l}\text { MAXIMUM } \\
(\mathbf{N})\end{array}$ \\
\hline \multirow{4}{*}{$\begin{array}{l}\text { Group I } \\
\text { (Teflon } \\
\text { coated NiTi) }\end{array}$} & I a & 6 & 1.66 & .49 & 1.25 & 2.60 \\
\cline { 2 - 7 } & I b & 6 & 1.48 & .54 & .50 & 1.85 \\
\hline $\begin{array}{l}\text { Group II } \\
\text { (Epoxy resin } \\
\text { coated NiTi) }\end{array}$ & II a & 6 & 1.95 & .50 & 1.15 & 2.50 \\
\cline { 2 - 7 } & II b & 6 & 1.41 & .16 & 1.20 & 1.60 \\
\hline $\begin{array}{l}\text { Group III } \\
\text { (Conventional } \\
\text { NiTi) }\end{array}$ & III a & 6 & 1.13 & .26 & .70 & 1.50 \\
\cline { 2 - 7 } & III b & 6 & 1.12 & .41 & .60 & 1.70 \\
\cline { 2 - 7 } & III c & 6 & 1.93 & .13 & 1.80 & 2.10 \\
\hline
\end{tabular}

Table 11:- Comparison of kinetic friction (N)

\begin{tabular}{|l|l|l|l|l|l|l|}
\hline \multicolumn{2}{|l|}{ GROUPS } & SAMPLE & $\begin{array}{l}\text { MEAN } \\
(\mathbf{N})\end{array}$ & $\begin{array}{l}\text { STD. } \\
\text { DEVIATION } \\
(\mathbf{N})\end{array}$ & $\begin{array}{l}\text { MINIMUM } \\
(\mathbf{N})\end{array}$ & $\begin{array}{l}\text { MAXIMUM } \\
(\mathbf{N})\end{array}$ \\
\hline \multirow{3}{*}{$\begin{array}{l}\text { Group I } \\
\text { (Teflon } \\
\text { coated NiTi) }\end{array}$} & I a & 6 & 1.61 & .47 & 1.02 & 2.44 \\
\cline { 2 - 7 } & I b & 6 & 1.38 & .55 & .51 & 1.87 \\
\hline $\begin{array}{l}\text { Group II } \\
\text { (Epoxy resin }\end{array}$ & 6 & 1.64 & .18 & 1.42 & 1.90 \\
\cline { 2 - 7 } & II a & 6 & 1.36 & .19 & 1.12 & 1.60 \\
\hline
\end{tabular}




\begin{tabular}{|l|l|l|l|l|l|l|}
\hline coated NiTi) & II c & 6 & .99 & .62 & .55 & 2.15 \\
\hline $\begin{array}{l}\text { Group III } \\
\text { (Conventional }\end{array}$ & III a & 6 & 1.97 & .12 & 1.82 & 2.16 \\
\cline { 2 - 7 } NiTi) & III b & 6 & 1.48 & .29 & 1.05 & 1.76 \\
\cline { 2 - 6 } & III c & 6 & 1.50 & .33 & 1.11 & 1.96 \\
\hline
\end{tabular}

Table 12:- Comparison of the loading force at $3 \mathrm{~mm}(\mathrm{~g})$

\begin{tabular}{|l|l|l|l|l|l|l|}
\hline \multicolumn{2}{|l|}{ GROUPS } & SAMPLE & $\begin{array}{l}\text { MEAN } \\
\text { (g) }\end{array}$ & $\begin{array}{l}\text { STD. } \\
\text { DEVIATION } \\
\text { (g) }\end{array}$ & $\begin{array}{l}\text { MINIMUM } \\
\text { (g) }\end{array}$ & $\begin{array}{l}\text { MAXIMUM } \\
(\mathbf{g})\end{array}$ \\
\hline \multirow{3}{*}{$\begin{array}{l}\text { Group I } \\
\text { (Teflon } \\
\text { coated NiTi) }\end{array}$} & I a & 6 & 2015.00 & 73.42 & 1910.00 & 2100.00 \\
\cline { 2 - 7 } & I b & 6 & 1781.67 & 66.16 & 1710.00 & 1890.00 \\
\hline $\begin{array}{l}\text { Group II } \\
\text { (Epoxy resin } \\
\text { coated NiTi) }\end{array}$ & II a & 6 & 1446.67 & 232.44 & 1010.00 & 1700.00 \\
\cline { 2 - 7 } & II b & 6 & 1701.67 & 171.05 & 1430.00 & 1860.00 \\
\hline $\begin{array}{l}\text { Group III } \\
\text { (Conventional } \\
\text { NiTi) }\end{array}$ & III a & 6 & 1593.33 & 64.70 & 1520.00 & 1690.00 \\
\cline { 2 - 7 } & III b & 6 & 1258.33 & 296.81 & 970.00 & 1590.00 \\
\cline { 2 - 7 } & III c & 6 & 1713.33 & 81.40 & 1600.00 & 1780.00 \\
\hline
\end{tabular}

Table 13:- Comparison of unloading forces between $2.5 \mathrm{~mm}-1.5 \mathrm{~mm}$ deflection $(\mathrm{g})$

\begin{tabular}{|l|l|l|l|l|l|l|}
\hline \multicolumn{2}{|l|}{ GROUPS } & SAMPLE & $\begin{array}{l}\text { MEAN } \\
\text { (g) }\end{array}$ & $\begin{array}{l}\text { STD. } \\
\text { DEVIATION } \\
\text { (g) }\end{array}$ & $\begin{array}{l}\text { MINIMUM } \\
\text { (g) }\end{array}$ & $\begin{array}{l}\text { MAXIMUM } \\
\text { (g) }\end{array}$ \\
\hline \multirow{3}{*}{$\begin{array}{l}\text { Group I } \\
\text { (Teflon } \\
\text { coated NiTi) }\end{array}$} & I a & 6 & 383.33 & 45.02 & 310.00 & 440.00 \\
\cline { 2 - 7 } & I b & 6 & 396.67 & 8.16 & 390.00 & 410.00 \\
\hline $\begin{array}{l}\text { Group II } \\
\text { (Epoxy resin } \\
\text { coated NiTi) }\end{array}$ & II a & 6 & 441.67 & 75.21 & 290.00 & 480.00 \\
\cline { 2 - 7 } & II b & 6 & 391.67 & 46.22 & 330.00 & 450.00 \\
\hline $\begin{array}{l}\text { Group III } \\
\text { (Conventional } \\
\text { NiTi) }\end{array}$ & III a & 6 & 321.67 & 31.89 & 280.00 & 360.00 \\
\cline { 2 - 7 } & III b & 6 & 258.33 & 25.63 & 220.00 & 300.00 \\
\cline { 2 - 7 } & III c & 6 & 350.00 & 34.64 & 300.00 & 400.00 \\
\hline
\end{tabular}

\section{Discussion:-}

The present study was carried out to compare the frictional properties and load deflection properties of conventional NiTi archwire and Coated NiTi archwires when placed in various types of ceramic brackets slots. One type of frictional force is the static frictional force that is present until movement starts, and the other is the kinetic frictional force that appears during movement ${ }^{8}$. Frictional resistance between archwire and brackets is caused by many factors and varies according to archwire size and material, mode of ligation, angulation of the wire to the bracket and saliva ${ }^{9}$.

Farronato $\mathrm{G}$ et $\mathrm{al}^{10}$ found that Teflon - coated archwires resulted lower friction than the corresponding uncoated archwires. Their results showed that Teflon coating has the potential to reduce resistance to sliding of orthodontic archwires. In the present study least static and kinetic friction was found when Epoxy Resin coated NiTi archwire was used with ceramic self ligating bracket $(1.12 \mathrm{~N}$, Table 10$)$ and $(0.99 \mathrm{~N}$, Table 11) respectively. Highest static frction was found when Teflon coated NiTi archwire was used with ceramic self ligating brackets (1.95 N, Table 10) and highest kinetic friction was seen when conventional NiTi archwire was used with ceramic bracket (1.97 N, Table 11). 
Among three different archwires, In Ceramic bracket and Ceramic Self Ligating bracket, lowest friction was seen in Epoxy Resin Coated NiTi arch wire and conventional NiTi produced highest friction. In Ceramic bracket with metal slot, lowest friction was seen in Epoxy Resin Coated NiTi arch wire and conventional NiTi produced highest friction.

Williams and Khaled Khalaf ${ }^{11}$ evaluated Frictional Resistance of Three Types of Ceramic Brackets and they found that Self ligating ceramic and metal slot ceramic bracket systems generated significantly less static frictional resistance than conventional ceramic bracket systems. Clarice Nishio et al ${ }^{12}$ also found in their study that ceramic bracket with a metal reinforced slot produced low friction as compared to traditional ceramic bracket with a ceramic slot which is similar to our study.

In Epoxy Resin coated NiTi archwire, lowest static and kinetic friction was seen in ceramic self ligating brackets (1.12 $\mathrm{N}$ and $0.99 \mathrm{~N}$ respectively, Table 10\&11) followed by ceramic bracket with metal slot $(1.13 \mathrm{~N}$ and $1.11 \mathrm{~N}$ respectively, Table $10 \& 11)$ and highest static and kinetic friction was seen in ceramic bracket (1.41 $\mathrm{N}$ and $1.36 \mathrm{~N}$ respectively, Table 10\&11).

But, In Teflon coated group, lowest static and kinetic friction was seen in ceramic bracket (1.48 $\mathrm{N}$ and $1.38 \mathrm{~N}$ respectively, Table 10\&11) with metal slot followed by ceramic brackets $(1.66 \mathrm{~N}$ and $1.61 \mathrm{~N}$ respectively, Table $10 \& 11)$ and highest static and kinetic friction was found in ceramic self ligating brackets (1.95 $\mathrm{N}$ and $1.64 \mathrm{~N}$ respectively, Table 10\&11) showing statistically no significant difference. In the present study, when Teflon coated NiTi wire was used with Ceramic self ligating brackets, tearing out of coating material was seen which could be a reason for increase in friction.

When wires are subjected to deflection in the horizontal or vertical directions, it is the load deflection properties that determine the biological nature of tooth movement. In this study we have measured the loading force at $3 \mathrm{~mm}$ deflection and unloading force i.e. force degradation between $2.5 \mathrm{~mm}-1.5 \mathrm{~mm}$ for each wire and bracket combination.

Shiva Alavi et al $^{3}$ conducted study to compare the load-deflection and surface properties of coated superelastic archwires with conventional superelastic archwires in conventional and metal-insert ceramic brackets. They found that Epoxyresin archwires produced lower forces compared to polycoated and conventional NiTi in conventional and metal - insert ceramic brackets. In our study, least loading force at $3 \mathrm{~mm}$ of deflection was seen when Epoxy Resin coated NiTi archwire used with ceramic self ligating bracket (1258.33 g, Table 12). Highest loading force was seen when Teflon coated NiTi archwire was used with ceramic bracket (2015.00 g, Table 12). In Ceramic bracket and Ceramic Self Ligating bracket, lowest loading force at $3 \mathrm{~mm}$ deflection was seen in Epoxy Resin Coated NiTi arch wire followed by conventional NiTi arch wire and Teflon coated NiTi archwire produced highest loading force at $3 \mathrm{~mm}$ deflection. Hind Abaas et $\mathrm{al}^{13}$ also in their study concluded that coated Epoxy wires produced lower forces compared to Polymer and Teflon coated round and rectangular archwire which are similar to our study.

In present study, least force degradation between $2.5 \mathrm{~mm}-1.5 \mathrm{~mm}$ deflection was seen in Epoxy Resin coated NiTi wire with ceramic self ligating brackets (258.33 g) and Teflon coated NiTi wire with ceramic bracket (441.67 g) showed highest force degradation among all the groups (Table 13).

Dayanne Lopes da Silva et al $^{14}$ evaluated Cross-section dimensions and mechanical properties of esthetic orthodontic coated archwires. They found that coated wires showed lower loading and unloading forces compared with uncoated wires and the authors suggested that the reduction of the inner alloy core dimensions seems to be the variable responsible for greater changes in the mechanical properties of coated archwires.

Disadvantages in durability and surface properties such as tearing and color changing of coated archwires in clinical conditions have been reported. Kusy ${ }^{15}$ stated that these coatings succumb to mastication forces and oral enzymes. In a study conducted by Elayyan et $\mathrm{al}^{16}$, loss of these coatings and increased roughness were reported after clinical use. Coatings are also reported vulnerable to mechanical and thermocycling stresses in vitro.

In the present study it was found that Epoxy Resin coated NiTi archwire showed superior frictional and load deflection properties as compared to Teflon coated Niti archwire and conventional NiTi archwire. Also, Ceramic 
self ligating bracket and ceramic bracket with metal slot showed better results as compared to conventional ceramic brackets.

\section{Conclusion:-}

From the results of the present study, It is suggested that:

1. Epoxy resin coating had more potential to reduce the friction as compared to Teflon coated archwire and conventional NiTi arch wire. Least static and kinetic friction was generated when using Epoxy resin coated NiTi archwire with ceramic self ligating bracket. Highest friction was seen when Teflon coated NiTi archwire was used with ceramic self ligating brackets.

2. Epoxy resin coated arch wire produced less loading and unloading forces as compared to Teflon coated archwire and conventional NiTi arch wire. Least loading force at $3 \mathrm{~mm}$ deflection and least force degradation were seen when using Epoxy resin coated NiTi archwire with ceramic self ligating bracket. Highest loading force at $3 \mathrm{~mm}$ deflection and least force degradation were seen when using Teflon coated NiTi archwire.

3. Ceramic self ligating brackets and ceramic brackets with metal slot produced low frictional forces as compared to conventional ceramic brackets.

4. It can be concluded that the Epoxy resin coated archwire and ceramic self ligating bracket is most efficient combination when esthetic appliance is the demand of the patient.

\section{References:-}

1. Sona Pabari, David R. Moles, and Susan J. Cunningham. Assessment of motivation and psychological characteristics of adult orthodontic patients. Am J Orthod Dentofacial Orthop 2011;140:263-272.

2. Russell J. Current Products and Practice Aesthetic Orthodontic Brackets. Journal Of Orthodontics.2005;32(2):146-163.

3. Alavi S, Hosseini N. Load-deflection and surface properties of coated and conventional superelastic orthodontic archwires in conventional and metal-insert ceramic brackets. Dental Research Journal. 2012;9(2):133-138.

4. Elayyan F, Silikas N, Bearn D. Ex vivo surface and mechanical properties of coated orthodontic archwires. European Journal Of Orthodontics [serial online]. December 2008;30(6):661-667.

5. Takeshi Mugurumaa; Masahiro Iijimab; William A. Brantleyc. Effects of a diamond-like carbon coating on the frictional properties of orthodontic wires. Angle Orthod. 2011;81:141-148.

6. 11. Kim Y, Cha J, Hwang C, Yu H, Tahk S. Comparison of frictional forces between aesthetic orthodontic coated wires and self-ligation brackets. Korean Journal Of Orthodontics.2014;44(4):157-167.

7. Anil Abdul Kaphoor and Shobha Sundareswaran. Aesthetic nickel titanium wires - how much do they deliver? European Journal of Orthodontics 34 (2012) 603-609.

8. Farronato G, Maijer R, Carìa M, Esposito L, Alberzoni D, Cacciatore G. The effect of Teflon coating on the resistance to sliding of orthodontic archwires. European Journal Of Orthodontics.2012;34(4):410-417.

9. Jakob SR, Matheus D, Jimenez-Pellegrin MC, Turssi CP, Amaral FLB. Comparative study of friction between metallic and conventional interactive self-ligating brackets in different alignment conditions. Dental Press $\mathbf{J}$ Orthod. 2014 May-June;19(3):82-9.

10. Leander D, Kumar JK. Comparative evaluation of frictional characteristics of coated low friction ligatures Super Slick Ties ${ }^{\mathrm{TM}}$ with conventional uncoated ligatures. Indian J Dent Res 2011;22:90-4.

11. Huang S, Huang J, Kang T, Diao D, Duan Y. Coating NiTi archwires with diamond-like carbon films: reducing fluoride-induced corrosion and improving frictional properties. Journal Of Materials Science. Materials In Medicine [serial online]. October 2013;24(10):2287-2292.

12. Kusy R, Whitley J. Frictional resistances of metal-lined ceramic brackets versus conventional stainless steel brackets and development of 3-D friction maps. The Angle Orthodontist. 2001;71(5):364-374.

13. Leite VV, Lopes MB, Gonini Júnior A, Almeida MR, Moura SK, Almeida RR. Comparison of frictional resistance between selfligating and conventional brackets tied with elastomeric and metal ligature in orthodontic archwires. Dental Press J Orthod. 2014 May-June;19(3):114-9.

14. Aghili H, Yasssaei S, Ahmadabadi M, Joshan N. Load Deflection Characteristics of Nickel Titanium Initial Archwires. Journal Of Dentistry (Tehran, Iran). September 2015;12(9):695-704.

15. Pasha A, Vishwakarma S, Narayan A, Vinay K, Shetty SV, Roy PP. Comparison of frictional forces generated by a new ceramic bracket with the conventional brackets using unconventional and conventional ligation system and the self-ligating brackets: An in vitro study. J Int Oral Health 2015;7(9):108-113.

16. Firas Elayyan,Nick Silikas,and David Bearn. Mechanical properties of coated superelastic archwires in conventional and self-ligating orthodontic brackets. Am J Orthod Dentofacial Orthop 2010;137:213-217. 